\title{
The role of food workers in food safety: A policy analysis of the U.S. 2011 Food Safety Modernization Act
}

\author{
Megan L. Clayton, ${ }^{\text {* }}$ Katherine Clegg Smith, ${ }^{\mathrm{b}}$ Lainie Rutkow, ${ }^{\mathrm{c}}$ and Roni A. Neff ${ }^{\mathrm{d}}$ \\ The Johns Hopkins Bloomberg School of Public Health
}

Submitted March 20, 2015 / Revised April 30, 2015 / Accepted May 18, 2015 /

Published online January 21, 2016

Citation: Clayton, M. L., Smith, K. C., Rutkow, L., \& Neff, R. A. (2016). The role of food workers in food safety: A policy analysis of the U.S. 2011 Food Safety Modernization Act. Journal of Agriculture, Food Systems, and Community Development, 6(2), 55-72. http://dx.doi.org/10.5304/jafscd.2016.062.004

Copyright (C) 2016 by New Leaf Associates, Inc.

\begin{abstract}
Foodborne disease is a significant problem in the United States and around the world. Though research identifies diverse factors associated with foodborne outbreaks, one of the most common is poor worker health and improper hygiene practice.

a * Corresponding author: Megan L. Clayton, PhD, Department of Health, Behavior and Society, The Johns Hopkins Bloomberg School of Public Health; 624 North Broadway Street; Baltimore, Maryland 21205 USA; mclayton@jhu.edu

b Katherine Clegg Smith, PhD, Department of Health, Behavior and Society, The Johns Hopkins Bloomberg School of Public Health; 624 North Broadway Street; Baltimore, Maryland 21205 USA; katecsmith@;hu.edu

c Lainie Rutkow, PhD, Department of Health Policy and Management, The Johns Hopkins Bloomberg School of Public Health; 624 North Broadway Street; Baltimore, Maryland 21205 USA; 1rutkow@jhu.edu

d Roni A. Neff, PhD, Department of Environmental Health Sciences, The Johns Hopkins Bloomberg School of Public Health; 624 North Broadway Street Baltimore, Maryland 21205 USA; and The Johns Hopkins Bloomberg School of Public Health Center for a Livable Future; 615 North Wolfe Street, Suite W7010; Baltimore, Maryland 21205 USA; rneff@jhu.edu
\end{abstract}

Research on social determinants of health indicates that living and working conditions play a role in shaping these risks. To start addressing these issues, we must first understand how we currently account for the role of workers in food safety. This qualitative study describes the role of workers in the Food and Drug Administration's (FDA) proposed regulations to implement the 2011 Food Safety Modernization Act, an unprecedented federal action to improve food safety. The analysis is guided by fundamental causes of disease theory, which provides a useful framework for exploring regulations within the context of the sociostructural factors that impact health and hygiene behavior. Findings reveal that proposed regulations primarily treat contamination by workers as an individual-level problem, including the result of workers' lack of food safety knowledge and need for education and training. With few exceptions, broader social and structural factors shaping workers' health and hygiene are overlooked. Study results may begin to change the food safety conversation by connecting the impact of macrosocial inequality on food workers to food safety and public health. 


\section{Keywords}

food policy, food safety, food workers, qualitative methods, fundamental causes of disease

\section{Introduction}

Foodborne disease represents a significant public health problem worldwide. Over the last 15 years, progress in addressing the problem in the United States has been stagnant (Centers for Disease Control and Prevention [CDC], n.d.-a). Though there are many sources of foodborne outbreaks, food workers across food work settings have been identified for decades as one of the most common (Greig, Todd, Bartleson, \& Michaels, 2007). According to the food safety literature, workers have been found to contaminate food through poor health and improper hygiene practices, including working while ill (Carpenter et al., 2013; CDC, n.d.-b; Clayton, Griffith, Price, \& Peters, 2002; U.S. Food and Drug Administration, Retail Food Program Steering Committee, 2000). Understanding and managing these worker-related hazards therefore is connected inherently to ensuring the safety of the food supply.

This study's objective is to identify accounts of the role of food workers in the U.S. FDA's proposed regulations to ensure safe food, and to consider relevant regulatory text in relation to theory and literature-based insights regarding social and structural influences on worker health and hygiene behaviors. This research adds to the literature by outlining current policy-based assumptions about sources of worker-related food contamination and the interventions that are sufficient to address the problem, both in the U.S. and globally. It also contributes a structural approach to understanding health and behavior, which broadens the range of factors identified as relevant for preventing worker-related foodborne disease. The results may inform future food safety regulations and interventions that better account for and support food workers in the goal of a prevention-based food safety system and a safer global food supply.

\section{A Profile of U.S. Food Workers and Working Conditions}

Approximately one-sixth of the U.S. workforce (20 million people) works in five key sectors of the food system: food production, processing, distribution, retail, and service (Food Chain Workers Alliance, 2012). Within these sectors, food service (where workers conduct food preparation, storage, and service in a variety of settings) represents over half of food workers. The average food worker is a non-Hispanic white, U.S.-born person whose primary language is English and who holds no more formal qualifications than a high school degree (Food Chain Workers Alliance, 2012). Approximately half of food workers are female and twothirds are 44 years old or younger. While most workers have lived in the U.S. for their entire lives, nearly one-quarter were born elsewhere (Ruggles, Alexander, Genadek, Goeken, Schroeder, \& Sobek, 2010). Most food jobs do not require formal training or credentials, and the food system provides opportunities to many undocumented workers who are likely underestimated in government labor data.

Worldwide, fresh produce has been increasingly linked to foodborne outbreaks, including from contamination during production (Lynch, Tauxe, \& Hedberg, 2009). In the United States, the production (or agricultural) sector employs approximately 3 million workers (the second largest sector, after service) who are identified as agricultural or farmworkers and who plant, manage, and pick raw foods, as well as raise livestock and farm fish. In addition to the challenges of poor wages and working conditions, agricultural jobs are some of the most hazardous in the nation. Farmworkers face regular risk of heat exhaustion and stroke, and compared to the general public they suffer higher rates of toxic chemical injury and pesticide exposure (Carroll, Samardick, Bernard, Gabbard, \& Hernandez, 2005; U.S. Department of Agriculture [USDA], Economic Research Service, 2008). The injury rate for agricultural work is $40 \%$ higher than the injury rate for all workers in general (Occupational Safety and Health Administration, n.d.). Additional health risks stem from living conditions; many farmworkers live in employerprovided housing, which has been found to be low quality, with crowding and poor sanitation (Quandt et al., 2013; USDA Economic Research Service, 2008). The risks faced by agricultural workers also include sexual harassment, given that reports from female farmworkers suggest they experience higher 
rates of sexual harassment than women in the general workforce (Southern Poverty Law Center, 2010; Waugh, 2010). Compounding these challenges, farmworkers are exempt from many basic federal labor protections, such as overtime pay requirements and protection for unionizing and collective bargaining (Farmworker Justice \& Oxfam America, 2010; U.S. Department of Labor, n.d.-a, 2009).

Although some food sector jobs provide a livable wage and opportunities for upward mobility, the majority offer low wages with little access to benefits, and few opportunities for advancement and training (Food Chain Workers Alliance, 2012; Lo \& Jacobsen, 2011). In one survey of workers across the food chain, 79\% reported a lack of paid sick days, $83 \%$ reported a lack of employer health insurance, and 86\% reported earning low or poverty wages (Food Chain Workers Alliance, 2012). Many food workers also find that inconsistent provision of wages and work hours challenges their ability to plan and achieve economic stability. For approximately $40 \%$ of food workers, making ends meet requires working for two or more employers for 40 hours a week and with little access to breaks (Food Chain Workers Alliance, 2012; Oxfam America, 2013).

Across the food system, workers indicate that reporting illness or injury can lead to negative consequences, including employer threats, wage and shift loss, and even termination (Food Chain Workers Alliance, 2012). Food workers also face barriers to accessing health services, including from a lack of health care providers in rural settings and from policy exemptions, such as partial or full exclusion of farmworkers from workers' compensation benefits in the majority of U.S. states (Holmes, 2013; Sakala, 1987; Villarejo, 2003). In addition to these factors, the majority of food workers also hold front-line positions, or jobs characterized by long hours of repetitive tasks, little decision-making, and lack of power in the workplace. Workers indicate that these conditions lead to prolonged experiences of illness, an inability to perform tasks adequately and safely, and a reliance on the emergency room for primary care (Food Chain Workers Alliance, 2012).
Fundamental Causes of Disease Theory,

Food Workers, and Foodborne Disease

Fundamental causes of disease theory identifies an important role for inequalities in macrosocial variables like income, environmental exposures, education, and housing, among others, in shaping health and its distribution in a population (Galtung, 1969; Goldberg, 2012; Link \& Phelan, 1995). According to this theory, the social and economic reality of many U.S. food workers limits their access to key resources (e.g., prestige, money, knowledge, power, and beneficial social connections) that are critical to health protection. As a result, many food workers face increased vulnerability to disease and injury, which also makes them a risk to the U.S. food supply (Link \& Phelan, 1995; Phelan, Link, \& Tehranifar, 2010).

The negative health effects of work have been recognized for centuries (Braveman, Egerter, \& Williams, 2011). Much less common, however, is research that describes how social and structural factors, like poor working conditions for food workers, affect health in a way that directly relates to food safety, such as studies on presenteeism (i.e., working while ill) (Johns, 2010). Research on presenteeism finds that working while sick is related to personal and work factors, including employee status in the work hierarchy and work policies such as pay, paid sick days, attendance control, downsizing, and permanency of employment (Johns, 2010, 2011). In a study on presenteeism among workers in a variety of work settings, Johns (2011) found that employees who perceived themselves as replaceable, held temporary status, and lacked a sense of job security were more likely to work when ill. The author suggests that these findings may reflect low-status workers who lack sufficient social standing to take time from work (Johns, 2011).

A few studies have begun to explore these issues in the food industry, including among food service and production workers. Study findings suggest a role for issues related to living and working conditions in shaping workers' health and hygiene behaviors, including restaurant workers' presenteeism due to concerns about short-staffing, lack of pay, and fear of job or shift loss, and farmworkers' high rates of communicable diseases 
related to low socioeconomic status, poor access to health care, and a lack of clean bathrooms (Carpenter et al., 2013; Clayton, Clegg Smith, Neff, Pollack, \& Ensminger, 2015; Holmes, 2013; Mobed, Gold, \& Schenker, 1992; Sakala, 1987). While it may be beneficial to provide training in safe food handling to food workers, fundamental causes likely underlie many hazards related to workers as a source of food contamination, playing a significant role in food safety and warranting much more attention in the food safety policy and research arenas.

\section{Modernizing U.S. Food Safety Systems}

In 2011, the U.S. Congress passed the Food Safety Modernization Act (FSMA), representing the largest overhaul of federal food safety laws in over 70 years. The law aims to transition an outdated and reactive food safety system into one that prevents foodborne disease in the first place (U.S. FDA, 2011). The FSMA also applies to both domestic and imported foods, which means that its accompanying regulations will affect food safety in the U.S. as well as globally. The FSMA directs the FDA to create regulations that implement the law. These regulations indicate how this federal agency currently envisions food safety and the role of food workers in this process.

\section{Methods}

\section{Documents}

In accordance with federal rulemaking, a key process by which the federal government implements policy, Congress has directed the FDA to develop rules that administer the FSMA (Carey, 2013). At the time of writing, the FDA has published proposed rules, also known as proposed regulations, to fulfill this responsibility and to create the central framework for a new food safety system in the U.S. (U.S. FDA, 2013a). Among these documents, the two rules that spell out requirements and standards for food workers were purposively selected for analysis. These proposed rules include (1) Current Good Manufacturing Practice and Hazard Analysis and Risk-Based Preventive Controls for Human Food (Section 105, FSMA) and (2) Standards for the Growing, Harvesting, Packing, and Holding of Produce for Human Consumption (Section 103,
FSMA). The remaining proposed rules focus on issues such as foreign supplier verification, intentional adulteration, and accreditation of third-party auditors and were not considered directly informative to the study aims.

The two selected proposed rules outline (1) the role of food workers within modern, science-, and risk-based preventive controls for human food that is manufactured, processed, packed, or held by a food facility (78 Fed. Reg., 3646) and (2) regulations for personnel qualifications and training, health and hygiene, and sanitary facilities that may ensure safety in the production and harvesting of fresh fruits and vegetables (78 Fed. Reg., 48637) ("Current good manufacturing practice and hazard analysis and risk-based preventive controls for human food," 2013; "Standards for growing, harvesting, packing, and holding of produce for human consumption," 2013). Though these requirements apply to workers in production, processing, and distribution sectors, as a part of a food system they affect food workers and food safety broadly.

\section{Content Search Strategy}

Proposed rules begin with preambles, which include summaries of the issues and actions being considered, invitations for public comment, and supplementary information, such as the legal authority for the rules, cited data, and compliance dates (Office of the Federal Register, 2011). Following the preamble, rules include regulatory text, or the proposed plans to address problems and meet goals outlined by the law. In this study, regulatory text across the two FDA proposed rules was reviewed for content on the role of workers in food safety and contamination, including text discussing worker health, hygiene, and related behaviors or practices; sanitation behaviors and practices; workers' social and structural context, such as living and working conditions; and any other text identified as related to study aims. In limited instances, proposed regulations concluded that some current worker requirements were "sufficient to address any [food safety] hazards" (78 Fed. Reg., 2013, p. 3743). These existing regulations were located in the Code of Federal Regulations and included in the analysis ("Current good manufacturing practice in manufacturing, 
packing, or holding human food," 2013). Table 1 outlines text segments identified as meeting study search criteria.

The search criteria and identified text were discussed and agreed upon by three of the study authors, including one with legal training. The lead author also read FDA guidance for industry on subparts of proposed rules to compare FDA thinking with study team interpretation of the proposed regulations.

\section{Coding and Analysis}

The selected text was coded and analyzed according to a framework approach. This approach supports policy-relevant qualitative research that begins deductively with pre-set study objectives (Pope, Ziebland, \& Mays, 2000). A coding framework was developed with five main coding categories: 1 -workers as hazards; 2 -living and working conditions as hazards; 3 -hazard controls;
4 - authority; and 5-regulatory frame. Four of these organizational categories were used to identify and sort data on concepts that were considered objectively clear (1 to 4), including text describing (1) how workers directly contaminate food (e.g., poor health and hygiene); (2) social or structural factors that influence workers as a source of food contamination (e.g., access to key resources, working terms and conditions, work environment, etc.); (3) interventions or requirements to address or reduce workers as a source of food contamination; and (4) the disciplines, institutions, qualifications, people, or positions that are authoritative in defining and implementing food safety. The additional category (5-regulatory frame) was added to capture content on how the FDA uses data, language, and problem definitions to frame food safety in relation to workers, which was considered to require subjective interpretation.

To test the clarity and consistency of category

Table 1. Text in the Proposed Rules that Implement the 2011 Food Safety Modernization Act and Relate to Food Workers

\begin{tabular}{|c|c|c|}
\hline $\begin{array}{l}\text { Proposed Rule or } \\
\text { Regulation }\end{array}$ & Part, Subpart & Section or Subsection \\
\hline \multirow{2}{*}{$\begin{array}{l}\text { Current Good } \\
\text { Manufacturing Practice } \\
\text { and Hazard Analysis and } \\
\text { Risk-Based Preventive } \\
\text { Controls for Human Food } \\
\text { (78 FR 3646) }\end{array}$} & $\begin{array}{l}\text { Proposed Revisions to Current } \\
\text { Good Manufacturing Practice } \\
\text { Requirements of Part } 110 \\
\text { (Proposed Part 117, Subpart } \\
\text { B, p. 3714) }\end{array}$ & $\begin{array}{l}\S 117.10 \text { Personnel } \\
\S 117.35 \text { Sanitary Operations } \\
\S 117.37 \text { Sanitary Facilities and Controls }\end{array}$ \\
\hline & $\begin{array}{l}\text { Proposed New Requirements } \\
\text { for Hazard Analysis and Risk- } \\
\text { Based Preventive Controls } \\
\text { (Proposed Part 117, Subpart } \\
\text { C, p. 3730) }\end{array}$ & $\begin{array}{l}\S 117.126 \text { Requirement for a Food Safety Plan } \\
\S 117.130 \text { Hazard Analysis } \\
\text { § } 117.135 \text { Preventive Controls for Hazards That Are } \\
\text { Reasonably Likely To Occur } \\
\text { § } 117.155 \text { Requirements Applicable to a Qualified Individual }\end{array}$ \\
\hline \multirow{2}{*}{$\begin{array}{l}\text { Standards for the } \\
\text { Growing, Harvesting, } \\
\text { Packing, and Holding of } \\
\text { Produce for Human } \\
\text { Consumption ( } 78 \text { FR } \\
48637 \text { ) }\end{array}$} & $\begin{array}{l}\text { Regulatory Approach (IV, p. } \\
\text { 3522) }\end{array}$ & $\begin{array}{l}\text { A. Qualitative Assessment of Risk } \\
\text { B. Focus on Biological Hazards }\end{array}$ \\
\hline & The Proposal (V, p. 3534) & $\begin{array}{l}\text { C. Standards Directed to Personnel Qualifications and } \\
\text { Training } \\
\text { D. Standards Directed to Health and Hygiene } \\
\text { L. Standards Directed to Equipment, Tools, Buildings, and } \\
\text { Sanitation }\end{array}$ \\
\hline \multirow{2}{*}{$\begin{array}{l}\text { Current Good } \\
\text { Manufacturing Practice in } \\
\text { Manufacturing, Packing, } \\
\text { or Holding Human Food } \\
\text { (21 CFR 110) }\end{array}$} & $\begin{array}{l}\text { General Provisions - Person- } \\
\text { nel (Subpart A, Sec. 110.10) }\end{array}$ & $\begin{array}{l}\text { 110.10a Disease Control } \\
\text { 110.10b Cleanliness (b1-b8) }\end{array}$ \\
\hline & $\begin{array}{l}\text { Buildings and Facilities - } \\
\text { Sanitary facilities and controls } \\
\text { (Subpart B, Sec. 110.37) }\end{array}$ & $\begin{array}{l}\text { 110.37a Water supply } \\
\text { 110.37b Plumbing (b1-b5) } \\
\text { 110.37c Sewage disposal }\end{array}$ \\
\hline
\end{tabular}

Note: The remaining sections that were not included related to plant and grounds, equipment, food recall plans, definitions of a qualified facility, recordkeeping requirements, foreign facilities, and other issues, such as nonworker hazards (e.g., soil amendments, domesticated and wild animals, agricultural water). 
definitions, a second coder was trained on a framework that included the four main objective codes ( 1 to 4 ) and excluded the subjective code (5). The lead author and the second coder independently and systematically applied these codes to all relevant text using Atlas.ti 7.1.8 qualitative data analysis and research software (Muhr, 2014). For this process, the lead author provided documents that demarcated the beginning and end of all selected sections of regulatory text (see Table 1). This step was seen as necessary as proposed federal regulations often include regulatory and nonregulatory content within a single section of text. Overall, coders had high agreement on codes 1, 2, and 4, but not 3 (hazard controls), which was found to capture the intended text plus additional data related to the omitted code (5-regulatory frame). In discussion with the second coder, it was determined that this additional text was seen as relevant to the study aims, but without an appropriate category for inclusion. After explaining the omission of coding category 5 , these discordances were clarified and agreed upon by coders. Throughout data analysis, memos were created to examine patterns within the data and to record emerging interpretations for analysis. The finalized body of coded text was reviewed for themes related to study objectives and fundamental causes theory, and for any concepts that emerged separately from these frameworks. During this process, codes 1 (workers as hazards) and 2 (working and living conditions as hazards) were maintained as separate subcategories, but organized under the broader category of workers as hazards to food safety. The subsequent organization of study results into 4 coding categories reflects this change.

\section{Results}

This section outlines the themes identified regarding the roles of food workers in food contamination and in protecting food safety according to the FDA's proposed regulations. Based on study aims, coding categories, and the guiding theoretical framework, these themes are organized into four categories: (1) food workers as hazards to food safety (including through health, hygiene, and living and working conditions); (2) controls for worker hazards; (3) authority to define and implement worker-related food safety; and (4) the regulatory frame shaping FDA interpretation of food workers in food safety. To further organize results, Table 2 summarizes study findings by coding categories and the reference location within FDA proposed rules.

\section{Food Workers as Hazards to Food Safety}

The proposed regulations predominantly discuss workers as a hazard to food at the individual level, or through their health, hygienic practices, and food handling behaviors. To a lesser extent, elements of workers' social status, such as literacy and language, are also considered. Beyond these factors, the proposed regulations mention some elements of working conditions as factors that may influence workers' ability to handle food safely. While these factors are recognized in the food safety literature as related to food contamination, and represent important concerns of effective food safety programs, the omission of consideration of additional complexities related to workers' health and food safety is potentially problematic.

\section{Worker Health, Hygiene, and Behavior}

Individual-level hazards described by the FDA's proposed regulations include workers' bodies, clothing, health status, hygiene, hygienic or health behaviors, and certain elements of workers' social status.

\section{Worker bodies, health, and personal effects}

At the most basic level, workers are classified as a source of food contamination because of various factors related to their bodies and health. These factors begin at the biological level and include workers as a source of food contamination because "humans (i.e., workers and visitors) are potential carriers of foodborne pathogens," including bacteria, parasites, and viruses (78 Fed. Reg., 2013, p. 3523). The proposed regulations label this route of foodborne pathogen transmission as poor worker health, which is defined as "an illness, open lesion, including boils, sores, or infected wounds, or any other abnormal source of microbial contamination” (78 Fed. Reg., 2013, p. 3802). Lastly, workers' health and bodies are further described as hazards because, in addition to being direct sources of food 


\section{Table 2. Results by Coding Category and Proposed Rule Section}

\begin{tabular}{|c|c|c|c|}
\hline Coding Category & Subcategory & Results & Proposed Rule Reference \\
\hline \multirow[t]{2}{*}{$\begin{array}{l}\text { Food workers as } \\
\text { hazards to food } \\
\text { safety }\end{array}$} & $\begin{array}{l}\text { Worker health, } \\
\text { hygiene, and } \\
\text { behavior }\end{array}$ & $\begin{array}{l}\text { Workers' bodies' poor health, personal effects; } \\
\text { inadequate hygiene and hygienic practice; social } \\
\text { status (low education, literacy levels) }\end{array}$ & $\begin{array}{l}78 \text { Fed. Reg., } 2013, \\
\text { p. } 3523 \text {, pp. } 3554-3555 \text {, } \\
\text { pp. } 3558-3559, \text { p. } 3802\end{array}$ \\
\hline & $\begin{array}{l}\text { Social and structural } \\
\text { conditions as } \\
\text { hazards to workers }\end{array}$ & $\begin{array}{l}\text { Physical facilities (inadequate toilets and hand- } \\
\text { washing stations, improper building and equip- } \\
\text { ment design); inadequate resources (gloves, } \\
\text { water, training materials); the nature of agricul- } \\
\text { tural jobs and/or conditions (long hours, large } \\
\text { work spaces, outdoors, transient employment) }\end{array}$ & $\begin{array}{l}78 \text { Fed. Reg., } 2013, \text { p. } \\
\text { 3523, pp. 3555-3556, } \\
\text { p. } 3559, \text { pp. } 3592-3593 \text {, } \\
\text { p. } 3803\end{array}$ \\
\hline \multirow[t]{2}{*}{$\begin{array}{l}\text { Controls for worker- } \\
\text { related hazards to } \\
\text { food safety }\end{array}$} & $\begin{array}{l}\text { Controls that target } \\
\text { individual-level } \\
\text { factors }\end{array}$ & $\begin{array}{l}\text { Food safety education and training, including } \\
\text { required hygienic practices, methods for } \\
\text { maintaining cleanliness, and requirements that } \\
\text { workers notify supervisors of illness and be } \\
\text { excluded from work while ill }\end{array}$ & $\begin{array}{l}78 \text { Fed. Reg., } 2013 \\
\text { pp. } 3554-3555 ; \text { pp. } \\
\text { 3742-3743, p. } 3802 ; \\
21 \text { C.F.R. pt. 2, } 2013\end{array}$ \\
\hline & $\begin{array}{l}\text { Controls that target } \\
\text { social and/or } \\
\text { structural factors }\end{array}$ & $\begin{array}{l}\text { Adequate sanitary facilities and equipment } \\
\text { (features, location, access, resources and } \\
\text { quality); cleanable food-contact surfaces; } \\
\text { standardized training materials and schedules }\end{array}$ & $\begin{array}{l}78 \text { Fed. Reg., 2013, p. } \\
\text { 3523, p. 3554, p. 3556, } \\
\text { pp. 3803-3804 }\end{array}$ \\
\hline \multirow[t]{2}{*}{$\begin{array}{l}\text { Authority in worker- } \\
\text { related food safety }\end{array}$} & Authorities & Owner, operator, or agent in charge of facility & $\begin{array}{l}78 \text { Fed. Reg., } 2013 \text {, } \\
\text { p. } 3733\end{array}$ \\
\hline & $\begin{array}{l}\text { Qualifications and } \\
\text { expertise }\end{array}$ & $\begin{array}{l}\text { Outside experts (trade and industry associations, } \\
\text { independent experts, regulatory authorities); } \\
\text { microbiologists, engineers, maintenance } \\
\text { supervisors; scientific and technical expertise }\end{array}$ & $\begin{array}{l}78 \text { Fed. Reg., } 2013 \\
\text { pp. } 3730-3731\end{array}$ \\
\hline \multirow[t]{4}{*}{ Regulatory frame } & Relevant data & $\begin{array}{l}\text { Food safety-related studies and perspectives; } \\
\text { background and training of FDA personnel }\end{array}$ & $\begin{array}{l}78 \text { Fed. Reg., } 2013 \\
\text { pp. } 3821-3824\end{array}$ \\
\hline & Problem scope & $\begin{array}{l}\text { Hazards that are biological; known, reasonably } \\
\text { foreseeable, and reasonably likely to occur; } \\
\text { identified and occur at the food facility }\end{array}$ & $\begin{array}{l}78 \text { Fed. Reg., 2013, } \\
\text { p. } 3732\end{array}$ \\
\hline & $\begin{array}{l}\text { Perspectives and } \\
\text { language }\end{array}$ & Worker controls as straightforward and universal & $\begin{array}{l}78 \text { Fed. Reg., } 2013 \text {, } \\
\text { p. } 3743\end{array}$ \\
\hline & & $\begin{array}{l}\text { Prevention of contamination by illness or } \\
\text { infection as workers' individual responsibility }\end{array}$ & $\begin{array}{l}78 \text { Fed. Reg., } 2013 \text {, } \\
\text { p. } 3557\end{array}$ \\
\hline
\end{tabular}

contamination, they may also transmit diseases to other workers, who may then transmit them to food.

The proposed regulations also recognize a role for workers' personal clothing or outer garments as factors that may harbor disease. In discussing standards for personnel during the harvesting, packing, and holding of raw fruits and vegetables, proposed regulations indicate that clothing may be contaminated with pathogens during work, and that "such contamination could be transferred from the clothing to [food]" (78 Fed. Reg., 2013, p. 3558).

\section{Worker hygiene and behavior}

The proposed regulations identify workers' hygiene and other behaviors as hazards to food. Proposed regulations described these hazards as "poor hygienic practices," "inadequate personal hygiene," "poor worker hygiene," and "inadequate hygienic practices among workers." These hazards are further broken down into specific behaviors, such as improper hand-washing (e.g., rinsing hands without using soap), improper glove maintenance (i.e., using gloves that are unsanitary or not intact), and touching food with bare hands. The proposed regulations cite research on individual-level sources of risk, such as a worker's "false sense of security" when using gloves, which can lead to unsanitary practices like "wearing the same gloves for an extended period of time without cleaning them, or 
washing hands infrequently" (78 Fed. Reg., 2013, p. 3559).

Worker behavior is also labeled as a hazard more broadly. The proposed regulations discuss an increased likelihood of food contamination from workers' "unsafe produce handling and storage practice," such as working while ill or touching food or food contact surfaces and not "[following] the correct food safety protocol" (78 Fed. Reg., 2013, pp. 3554-3555). Workers are also implicated for "[failing] to identify a situation that may result in contamination of food that is grown, harvested, packed, or held” (78 Fed. Reg., 2013, p. 3554).

\section{Workers' social status}

To a limited extent, the proposed regulations suggest that workers' level of education and literacy are relevant to food safety. Workers specifically are mentioned as factors that may impede effective implementation of food safety activities, such as food worker training. For example, in describing the development of new food safety training materials, the proposed regulations discuss the expectation that they be designed in a way to "help overcome literacy issues" (78 Fed. Reg., 2013, p. 3554).

\section{Social and Structural Conditions as Hazards to Workers}

Although the majority of the relevant text discusses workers as a direct hazard to food safety, as described in the sections above, some sections of the proposed regulations also consider how social and structural factors may influence workers as a source of food contamination, primarily through their effects on worker hygiene behaviors and related activities. As defined by the proposed regulations, the factors considered include the immediate work environment and relate to physical facilities, resources, and certain characteristics of jobs and working conditions in the production and processing sectors.

\section{Physical facilities}

Proposed regulations mention aspects of the physical work environment that may influence the likelihood that worker-related hazards lead to contamination. For example, in some sections there is a recognition of a role for sanitary facilities, including hand-washing stations and toilets. At a fundamental level, the proposed regulations state that a sanitary facility "produces waste that can lead to contamination" (78 Fed. Reg., 2013, p. 3593). Thus the proposed regulations define an inadequate sanitary facility as "a portable toilet facility that leaks or a fixed toilet facility that lacks proper drainage or backflow devices," which may contribute runoff and contaminate food, soil, or water (78 Fed. Reg., 2013, p. 3592). The idea of facility inadequacy was also extended to facilities' locations or distances, frequency of cleaning, and the appropriate number of toilets and hand-washing stations. For example, the proposed regulations mention that sanitary facilities can be sources of hazards if their placement does not account for the layout of a production facility, or, in the case of fruits and vegetables, that "the growing area of a farm may spread across several acres of land" (78 Fed. Reg., 2013, pp. 3592-3593).

The design of work buildings and equipment is also considered as a hazard to worker-related food safety. The influence of "improper design" is characterized as food-contact surfaces and related workplace equipment that are difficult for food workers to access and clean (78 Fed. Reg., 2013, p. 3803).

\section{Resources}

The proposed regulations include some consideration for how inadequate resources in the work environment may influence food workers as sources of food contamination. These resources fall into two main categories: health and hygienerelated resources and training-related resources.

Discussion of hygiene-related resources as a hazard is limited to gloves and water. A brief section of text explained that gloves, themselves, "can transfer pathogens to [food] if the gloves become contaminated” (78 Fed. Reg., 2013, p. 3559). As a result, the proposed regulations recognize a role for gloves, when "dirty and damaged," to influence the extent to which workers may handle food safely (78 Fed. Reg., 2013, p. 3523). The proposed regulations also consider a role for water quality (e.g., water contaminated with pathogens) in shaping worker-related hazards such as poor hygiene. 
Another resource related to workers as hazards is training. Training is identified as a factor that may influence the extent to which workers' education level and literacy are hazards to food safety. Worker training and training materials are described as hazards when they are designed and delivered in a way such that "the person receiving the training cannot understand it" (78 Fed. Reg., 2013, p. 3555).

The nature of jobs and working conditions Apart from inadequate facilities, equipment, and resources, the proposed regulations reserve a limited amount of text to discuss workers' day-today working conditions and the nature of agricultural jobs as potential sources of influence on worker-related food contamination.

One proposed rule focuses specifically on workers in produce packing, processing, and holding facilities. Work schedules in relation to the farm work environment (e.g., "workers may be in growing areas for extended periods of time") are specifically considered as factors that may affect worker-related food safety, such as workers' hygiene practice and proper use of sanitary facilities (78 Fed. Reg., 2013, p. 3593). The proposed regulations also mention that farm work is done predominantly outside and that the nature of this environment may influence the extent to which workers may contaminate food. The proposed regulations explain,

The outdoor nature of many areas where covered activities take place naturally presents workers with situations where they will get dirt on their hands, and workers may be routinely handling food, with their bare hands, that will not be cooked to adequately reduce pathogens.

(78 Fed. Reg., 2013, p. 3559)

Beyond day-to-day working conditions, a few sections discuss the "transient nature" of agricultural jobs (including workers who are temporary, part-time, seasonal, and contracted) as a factor that may influence the ability of food facilities to address worker-related food hazards (78 Fed. Reg.,
2013 , p. 3633). For example, the proposed regulations describe the challenge of reaching workers and ensuring delivery of food safety training in situations where farms "employ contracted harvest crews" and workers "move from farm to farm under the employment of the harvest crew company" (78 Fed. Reg., 2013, p. 3556).

\section{Controls for Worker-Related Hazards to Food Safety}

The proposed regulations identify controls (or requirements) that are described as sufficient to "significantly minimize or prevent [worker-related hazards] in order to prevent illness or injury" (78 Fed. Reg., 2013, p. 3731). These controls can be seen as further indication of FDA's understanding of the primary factors shaping the role of workers in food contamination. In this section, results are organized into two categories: (1) controls that target individual-level sources of worker hazards, and (2) controls that target social and/or structural sources of worker hazards.

\section{Controls that target individual-level factors}

Across the range of proposed controls for workerrelated hazards, most focus on the individual level. These controls explain poor worker health, hygiene, and inadequate hygienic behaviors as issues of low knowledge and skill that are controllable through education and training. For example, highlighting the perceived importance of food safety knowledge in shaping workers' ability to handle food safely, the proposed regulations explain,

Educating personnel who conduct covered activities in which they contact covered produce and supervisors about food hygiene, food safety, and the risks to produce safety associated with illnesses and inadequate personal hygiene is a simple step that can be taken to reduce the likelihood of pathogens being spread from or by personnel to covered produce. (78 Fed. Reg., 2013, p. 3554)

In addition to food safety education, the proposed regulations highlight a role for specific hygienic practices (or behaviors) as methods for 
"maintaining cleanliness," managing hazards of health and disease, and ensuring sanitation (78 Fed. Reg., 2013, p. 3802). To maintain cleanliness, workers are to be instructed on proper outer garment use, jewelry use, hand washing, glove maintenance, use of effective hair restraints, and the storage of personal clothing, belongings, or equipment. Workers are also to be informed on where they may eat, chew gum, drink, or use tobacco, and to take precautions to prevent food contamination from other "foreign" substances, including sweat, hair, cosmetics, tobacco, chemicals, and medicine applied to skin (21 C.F.R. pt. 2, 2013; 78 Fed. Reg., 2013, p. 3802).

With regard to further controlling worker health and disease, ill workers are to be "excluded from operations where their presence could lead to contamination of food," and they are instructed to "notify their supervisor(s) (or responsible party) if they have, or if there is a reasonable possibility that they have, an applicable health condition" (78 Fed. Reg., 2013, p. 3743; 78 Fed. Reg., 2013, p. 3557). The proposed regulations also outline that food facilities should ensure sanitation by developing procedures that ensure that workers "do not touch insanitary objects (e.g. waste, trash cans, the floor, and restroom fixtures or surfaces) and then food, food-contact surfaces, or food packaging materials," without first washing hands (78 Fed.Reg., 2013, p. 3742).

Similar to requirements for food safety education, the proposed regulations aim to ensure food safety knowledge and behavioral requirements through training, a focus that underscores the FDA's perception that worker knowledge is central in shaping food workers' health and hygienic behavior as sources of contamination. As the agency asserts,

Because ensuring that covered produce is not contaminated is dependent on personnel following proper food safety and hygiene practices, all personnel who contact covered produce and food-contact surfaces must receive training. (78 Fed. Reg., 2013, p. 3555)

Alongside instruction on food safety, the aforementioned hygienic practices, and "the danger of poor personal hygiene and insanitary practice," the proposed regulations also call for worker training on how to recognize, inspect, and correct various food, equipment, and food container hazards (78 Fed. Reg., 2013, p. 3802; 78 Fed. Reg., 2013, pp. 3554-3556). Together, this instruction represents what the proposed regulations identify as minimum qualification and training standards necessary to minimize worker-related risks for food contamination.

By focusing on training and adherence to specific sanitary practices, the proposed regulations construct worker knowledge and skills as primary factors that determine the role of workers in food contamination, or poor worker health and inadequate hygienic practice.

\section{Controls that target social and/ or structural factors}

A more limited amount of text from the proposed regulations describes controls for certain social and structural factors identified as affecting workers' ability to handle food safely. These controls relate to (1) sanitary facilities, such as toilets and handwashing stations, and (2) training materials and schedules. Together, these controls identify regulatory interpretation of the range of social and structural factors that are relevant to the role of food workers in food safety. They also outline the boundaries of perceived responsibility for the U.S. food safety system in relation to addressing worker-related food contamination.

\section{Adequate sanitary facilities}

The proposed regulations assert that controlling worker-related hazards requires adequate and readily accessible worker toilets and hand-washing stations. The proposed regulations define adequacy through a number of detailed facility specifications. These details cover equipment features (e.g., water that is safe, sanitary, of suitable temperature and pressure; plumbing and sewage disposal of adequate size and design to convey waste), location and access (i.e., accessible to workers and cleaning services but away from water sources, distribution systems, and "at a reasonable distance from growing and packing areas"), and overall quality (e.g., clean, well-maintained, and stocked with soap, 
toilet paper, and drying devices) (78 Fed. Reg., 2013, pp. 3803-3804; 78 Fed. Reg., 2013, p. 3592).

Though requirements related to the specific number of toilets to number of workers, maximum worker-to-restroom distance, and frequency of facility cleaning are not specified by the proposed regulations, the text connects these factors to food safety by pointing out that these requirements are to be attended to as prescribed by the Occupational Safety and Health Administration (OSHA) under the Occupational Safety and Health Act (specifically, 29 CFR 1928.10).

For these facility and resource requirements, the proposed regulations explain the influence on workers' food safety-related behaviors: "workers are more likely to use toilet facilities that are clean, well-stocked, and in good condition" (78 Fed. Reg., 2013, p. 3592). In addition to controls for sanitary facilities, the proposed regulations require that food-contact surfaces be designed in a way that is cleanable (78 Fed. Reg., 2013, p. 3523; 78 Fed. Reg., 2013, p. 3804). Together, these sections indicate that the proposed regulations account for elements of the immediate physical work environment, including workplace facilities and design, in shaping the role of workers in food contamination.

\section{Training materials and schedules}

The proposed regulations identify requirements for the design of worker training materials. These specifications are meant to address "poor training" and incomprehension (including that related to workers' level of education and literacy issues), which are described as "likely contributing factors" to foodborne outbreaks and contamination (78 Fed. Reg., 2013, p. 3554). The proposed regulations explain these design requirements as follows:

Training could be understood by personnel being trained if, for example, it was conducted in the language that employees customarily speak and at the appropriate level of education. In some cases in may be necessary to use easily understood pictorials or graphics of important concepts. 78 Fed. Reg., 2013, p. 3555)

To account for these resource-related and worker-related hazards together, the proposed regulations call for the creation of training materials that are "standardized, multi-formatted, and multi-lingual, and available in pictorial format" (78 Fed. Reg., 2013, p. 3554).

In addition to training material design, the proposed regulations outline requirements for training schedules to address the transient nature of agricultural work. Specifically, in order to account for temporary, part-time, and seasonal agricultural workers, the proposed regulations specify that training must be made available upon hiring, at the beginning of each growing season, and periodically thereafter. In the case of workers who are employed on farms through harvest crew companies, the FDA outlines expectations that these companies provide training and verification thereof to farms (78 Fed. Reg., 2013, p. 3556).

\section{Authority in Worker-Related Food Safety}

The proposed regulations specify a variety of stakeholders, disciplines, and knowledge requirements that are seen as authoritative for developing, implementing, and controlling the food safety process. In this section, indications of the FDA's perception about whom and what should have power in worker-related food safety are described according to two main themes: (1) authorities assigned to create, manage, and define food safety; and (2) qualifications and expertise relevant to food safety.

\section{Authorities assigned to create, manage, and define food safety}

As a central part of the proposed regulations, facility management is required to develop written food safety plans. These plans document information about the preventive controls for a given facility, which include evaluations of food safety hazards, controls, and steps to monitor controls and to correct problems when they may occur. The proposed regulations described these plans as intended for use by auditors, inspectors, and a facility food safety team (discussed below under "Relevant qualifications and expertise"). They are also seen as tools for employee training, or to "make employees aware of food safety hazards" (78 Fed. Reg., 2013, p. 3733). As a whole, the food safety plan defines the food safety structure and process for a given 
food facility, including the role of workers in this system. Though this plan affects and relates to all stakeholders of a facility, the authority to design and ensure requirements, including those for workers, is given to the owner, operator, or agent in charge of a facility; there is no discussion of required or recommended worker engagement.

\section{Relevant qualifications and expertise}

In addition to recognizing the roles of management or the owner, operator, or agent in charge of a facility, the proposed regulations identify specific industries and disciplines that command authority in defining and ensuring food safety. For example, in developing food safety plans, the proposed regulations allow involvement from "outside experts," which are defined as trade and industry associations, independent experts, and regulatory authorities (78 Fed. Reg., 2013, p. 3730). The proposed regulations also mention that plans may be defined using a food safety team, which may include people who "bring specific expertise important in developing the plan" (78 Fed. Reg., 2013, p. 3731). Examples of eligible team members are described as a microbiologist who understands microbial hazards, an engineer with knowledge of heat treatments, and a maintenance supervisor who understands metal contamination (78 Fed. Reg., 2013, p. 3731).

All identified experts are subject to the proposed regulation's definitions of a "qualified individual." This title outlines the type of knowledge perceived to be relevant to define and ensure food safety for a given food facility. The proposed regulations explicitly state that this knowledge, which relates to food safety controls, hazards, and their associated monitoring and corrective actions, requires "scientific and technical expertise developed through training, experience, or both" (78 Fed. Reg., 2013, p. 3731).

\section{The Food Worker Regulatory Frame}

Stepping back from the literal guidance provided by the FDA on food workers and food safety, this section analyzes the underlying approach taken by the FDA in framing the proposed regulations. The role of workers in food safety is shaped by the FDA's decisions about which data are relevant to inform regulations, the definition of the scope of a problem and its solution, and the perspectives and language used to explain worker-related controls and hazards.

\section{Data considered relevant to food safety regulations}

The proposed regulations are described by the FDA as comprehensive and science-based. They are built from a foundation of literature identified by the FDA as relevant to food safety-defined as food safety data that are available. This characterization indicates that the proposed regulations (prior to accounting for input from commenters during the public comment process) are limited to evidence from studies and perspectives under the food safety umbrella, such as those currently published in food safety journals. The selection and interpretation of these data are further shaped, necessarily, by the backgrounds and training of the FDA personnel in charge of drafting the proposed regulations.

\section{Definition of the scope of the problem and its solution} The problem of food contamination, including interpretation of the role of food workers, is oriented around identifying and controlling biological hazards that occur at the point of the farm or within the walls of the food facility. Hazards are defined as known, reasonably foreseeable, and reasonably likely to occur, and they are analyzed with food as the focal point, or, "for each type of food manufactured, processed, packed, or held at the facility" (78 Fed. Reg., 2013, p. 3732). Hazard analysis in relation to workers, therefore, is considered at the point of worker interaction with food, rather than at other levels of the food system process, such as broader social and structural factors shaping workers' health and hygiene practice.

\section{Perspectives and language for worker-related controls and hazards}

In limited instances, the proposed regulations include statements of opinion or make choices about appropriate language that reveal what may be dominant perspectives within FDA on the genesis of poor health and hygiene behaviors in the food safety arena. For example, the proposed regulations 
include documentation requirements for food safety plans. For controls to manage workers who are ill or infected, the proposed regulations make an exception that reveals a subjective interpretation of the ease with which human health and behavior can be understood and controlled:

A requirement in this regulation to develop written procedures for ensuring that this condition is met does not appear to be necessary, given the rather straightforward and universal nature of the controls (i.e., observe employees for signs of illness and redirect their activities accordingly). (78 Fed. Reg., 2013, p. 3743)

In another section, the provision requiring employees to report illness emphasizes that "individual workers have a responsibility - every day - to take action to prevent contamination due to their own illness or infection" (78 Fed. Reg., 2013, p. 3557). This statement individualizes the role of the food worker in food contamination and defines workers as rationally acting individuals who have complete control over their health and hygiene.

\section{Discussion}

The proposed rules document federal agency plans to address a problem or achieve a goal (Office of the Federal Register, 2011). The FDA's proposed rules to implement the 2011 Food Safety Modernization Act provide valuable insight about how the federal agency accounts for food workers in food contamination and safety in domestic and foreign food systems. These official documents include information about how food workers are legally constructed as hazards to food and the FDA's perceptions regarding the sources of influence for these risks, such as workers' lack of food safety knowledge and skills. Agency plans also describe methods for controlling the hazards, and these approaches shape national and international norms around appropriate food safety interventions and food facility responsibility in supporting worker health and hygiene to ensure safe food.

The proposed rules provide examples of FDA perceptions that individual-level factors represent central sources of risk for food and for food workers in food contamination. For example, workers are described as direct hazards to food through poor health and hygiene behaviors, including illness, inadequate personal cleanliness and sanitation, and unsanitary clothing. Among the factors that are identified as sources for these risks, the proposed regulations focus on insufficient food safety knowledge and skills. In some sections, proper health and hygiene are defined as issues of worker responsibility.

In line with food safety literature, these factors represent some of the key proximal risk factors for food safety threats, and workers' food safety knowledge and skills, through training, represent important components of effective food control programs. Yet the responsibility for these hazards, and their remedy, may not be most appropriately placed on workers, and there is a need to look beyond the individual for social and structural root causes. Further, by interpreting the source of worker-related food contamination as within (or on) food workers, the proposed regulations also assume a sense of responsibility toward food work that may not be perceived when providers of food jobs are not acting responsibly toward workers (e.g., through low wages and lack of access to benefits). These dominant interpretations may relate, in part, to the FDA's reliance on a regulatory frame that is informed by food safety data and a goal of identifying biological, facility-based hazards to food.

The proposed regulations provide some evidence that federal-level food safety systems account for social and structural context as a source of influence in worker-related contamination. For example, the proposed regulations consider that workers' hygiene practice and access to training may be affected by the physical work environment and resources (large outdoor work spaces, improperly functioning sanitation facilities, damaged gloves), work schedules (long hours), and certain aspects of agricultural work (transient and varied terms of employment). However, despite the fundamental role for other social and structural factors, such as workers' poor living and working conditions-including experiences of poverty and low-quality housing, low wages, poor treatment, 
and lack of access to benefits-in shaping worker health (including anxiety, chronic stress, and infectious disease), these factors are noticeably absent from the proposed regulations' definitions of workers as a source of food contamination.

These legal constructions of the role of food workers in food safety, including factors that contribute to contamination, shape the types of interventions that are prioritized and perceived as appropriate to manage the issue. For example, the limited consideration for workers' social and structural context is reflected in the few interventions for adequate facility design and resources, which are identified to support food safety knowledge and proper hygienic practice rather than to help protect and promote workers' fundamental health. Further, though damaged gloves and personal clothing are implicated as sources of worker-related contamination, proposed controls focus on proper use, rather than workers' access to proper materials, including personal protective equipment. The primary focus of controls for workers, instead of controls for workers' context (social and structural environment), is underscored by proposed requirements to largely manage contamination by workers through training. As a core component of a prevention-oriented food safety framework, this requirement implies that worker experiences of poor health and improper hygiene are rooted in a lack of food safety knowledge and skill, which may be managed largely through work-based, targeted training around safety practices.

Even though food workers are often most closely connected to opportunities and barriers to implementing proper health and hygiene practice, these findings show that proposed regulations do not involve workers in opportunities to analyze and define food safety hazards and plans. This marginalization of workers is evident in proposed requirements that assign food safety authority to higherlevel employees, and that suggest examples of food safety experts are those with training in scientific or technical fields. Given research that finds most food workers operate in front-line positions and, on average, hold a high school degree or less, these requirements systematically exclude the majority of food workers from the development, implementation, and enforcement of food safety systems in their place of work. Accordingly, the proposed regulations omit an important opportunity to learn the insider perspectives of those whose behavior and health they aim to manage and change, and who may be most familiar with the relevant processes (Mitchell, Fraser, \& Bearon, 2007).

Theory on social conditions as fundamental causes of disease posits that food safety policy that aims to account for workers' health and health behavior must also account for the broader macrolevel structures, such as poor working conditions, by which these factors are shaped. For more effective food safety interventions, the FSMA and future food safety policy must attach working conditions (including worker pay, benefits, access to health and hygiene-related resources, and treatment) to food hazard definitions and control requirements. Stronger connections should be made between workers' housing, occupational health, and/or safety protections and safe food. Food workers must also be explicitly recognized as sources of food safety authority and, accordingly, be represented on food safety teams that develop and implement facility food safety processes. At the national policy level, workers' participation in food safety may be supported by worker centers, unions, and national coalitions of food-worker organizations such as the Food Chain Workers Alliance. These groups may facilitate broad worker engagement in the public comment process, where workers' perspectives on key food safety hazards and controls may directly inform future food safety rules.

There are a few organizations that have begun to encourage worker involvement in food safety and working conditions through independent labor standards. Two examples of these programs are Oxfam's Equitable Food Initiative (EFI) and the Coalition of Immokalee Workers' Fair Food Program (FFP). For EFI, independent standards for working conditions and worker involvement are explicitly joined with standards for pesticide management and food safety, such that the issues are understood as interrelated and perceived as mutually enforcing (Equitable Food Initiative, 2014). The FFP aims to "affirm the human rights of [Florida] tomato workers and improve the conditions in which they labor," where a food 
safety connection is not explicit (Coalition of Immokalee Workers, n.d., para. 2). Nevertheless, both programs work through partnership among produce workers, growers (or employers), and retailers to promote working conditions, health, and safety above and beyond the requirements established by existing government regulations and labor protections.

These programs represent valuable case studies to better understand and address poor working conditions as an issue of food and public safety. Public health researchers and practitioners should be pay attention to and promote the evaluation of these efforts, particularly with regard to the impact of each standard on workers' health and hygiene practice and for reducing food contamination and outbreaks. As each program includes diverse components or tools to improve working conditions, these programs also represent opportunities to identify new food safety indicators and points for intervention that are directly related to working conditions. Supporting and investigating these programs will be important to future food safety research as well as for enhancing local, state, and federal government frameworks for ensuring safe food.

There are some limitations to the analysis presented. The density and complex language of the proposed regulations may mean that certain nuances characterizing food workers in food safety were missed. However, careful and repeated review of study documents, inclusion of second-coder verification, and input from researchers with legal training were used to help address this potential. Results should also be interpreted with the understanding that reviewed food safety provisions were in a proposed state; the FDA has since received and incorporated comments from the public. It may also take years before the rules are implemented. Though rules may change in their final form, FDA memos and supplemental proposals suggest that the worker-related sections analyzed in this paper are unlikely to be revised (U.S. Food and Drug Administration, 2013a, 2013b, 2014). Finally, the discussion is partly premised on the idea that the amount of text devoted to an issue reflects importance, and this may not be so. Despite these limitations, the reviewed documents are instructive for understanding how the FDA currently thinks about, and shapes the foundation for addressing, the role of food workers in food contamination and food safety.

\section{Conclusion}

The findings from this study describe the framework by which the FDA defines and aims to manage the role of food workers in U.S. food safety systems. Despite literature documenting the impact of food workers' poor living and working conditions on worker health and hygiene behaviors, results indicate that these factors are largely absent from the proposed regulations' definitions of workers as a source of food contamination and interventions to prevent food contamination by workers. Even though the proposed regulations represent minimum food safety standards specifically for food production, processing, and distribution facilities, their definitions of relevant food safety authorities exclude food workers, whose insights could be essential in driving effective practice to improve safe food handling.

The disconnect between food workers' social and structural context and regulations to address their role in food contamination represents a critical food safety issue that may lead to insufficient food protection and increased risks for both worker and consumer health. By defining workerrelated contamination as largely due to knowledge and training - and not macro-level factors that also shape workers' health and hygiene- the proposed rules may also support a system that responds to foodborne disease by blaming the worker.

Future research should continue to build the evidence base clarifying the impact of poor living and working conditions on food workers, food safety, and public health. This work may also explore opportunities to improve the visibility of these issues among policymakers and on the public policy agenda. Such efforts may benefit from collaborations among researchers and practitioners in social science, groups focused on food working conditions and food safety, and food workers across sectors. Though these stakeholders are not recognized as relevant to food safety in the proposed regulations, their unique perspectives on the 
factors shaping health and hygiene may help to build more effective interventions to prevent contamination by workers. Finally, these groups should disseminate this work by taking advantage of federal rulemaking opportunities to shape and inform future food safety regulations, such as through participation in the public comment process.

\section{References}

Braveman, P., Egerter, S., \& Williams, D. R. (2011). The social determinants of health: Coming of age [Review]. Annual Review of Public Health, 32, 381398. http://dx.doi.org/10.1146/annurevpublhealth-031210-101218

Carey, M. P. (2013). Counting regulations: An overview of rulemaking, types of federal regulations, and pages in the Federal Register. Washington, D.C.: Congressional Research Service.

Carpenter, L. R., Green, A. L., Norton, D. M., Frick, R., Tobin-D’Angelo, M., Reimann, D. W.,...Le, B. (2013). Food worker experiences with and beliefs about working while ill. Journal of Food Protection, 76(12), 2146-2154. http://dx.doi.org/10.4315/0362-028X.JFP-13-128

Carroll, D. J., Samardick, R. M., Bernard, S., Gabbard, S., \& Hernandez, T. (2005). Findings from the National Agricultural Workers Survey (NAWS) 2001-2002: A demographic and employment profile of United States farm workers (Research Report No. 9). Washington, D.C.: U.S. Department of Labor.

Centers for Disease Control and Prevention [CDC]. (n.d.-a). Estimates of foodborne illness in the United States. Retrieved February 4, 2013, from http://www.cdc.gov/foodborneburden/

CDC. (n.d.-b). CDC and food safety. Retrieved February 4, 2013, from http://www.cdc.gov/ foodsafety/cdc-and-food-safety.html

Clayton, D. A., Griffith, C. J., Price, P., \& Peters, A. C. (2002). Food handlers' beliefs and self-reported practices. International Journal of Environmental Health Research, 12(1), 25-39. http://dx.doi.org/10.1080/09603120120110031

Coalition of Immokalee Workers. (n.d.). The Fair Food Program: Frequently asked questions Retrieved September 4, 2014;_archived at https://web.archive.org/web/20141203191136/htt $\mathrm{p}: / /$ ciw-online.org/ffp faq/

Current good manufacturing practice and hazard analysis and risk-based preventive controls for human food, 78 Office of the Federal Register 3646. (January 16, 2013) (to be codified at 21 Code of Federal Regulations pts. 1, 11, 16, 106, 110, 114, 117, 120, 123, 129, 179, and 211).

Current good manufacturing practice in manufacturing, packing, or holding human food, 21 Code of Federal Regulations (April 1, 2013).

Equitable Food Initiative. (2014). Equitable Food Initiative. Retrieved September 4, 2014, from http://www.equitablefood.org/

Farmworker Justice \& Oxfam America. (2010). Weeding out abuses: Recommendations for a law-abiding farm labor system. Washington, D.C.: Authors. Retrieved from https://www.farmworkerjustice.org/sites/default/f iles/documents /7.2.a.7\%20weeding-out-abuses.pdf

Food Chain Workers Alliance. (2012). The hands that feed us: Challenges and opportunities for workers along the food chain. Los Angeles: Author. Retrieved from http://foodchainworkers.org/wp-content/up loads/2012/06/Hands-That-Feed-Us-Report.pdf

Galtung, J. (1969). Violence, peace, and peace research. Journal of Peace Research, 6(3), 167-191. http://dx.doi.org/10.1177/002234336900600301

Goldberg, D. S. (2012). The difficulties of enhancing public understanding of the social determinants of health in the United States: A commentary on Pesce, Kpaduwa, Danis (2011) [Commentary]. Social Science and Medicine, 74(8), 1139-1142; discussion 1143-1145. http://dx.doi.org/10.1016/j.socscimed.2011.11.040

Greig, J. D., Todd, E. C. D., Bartleson, C. A., \& Michaels, B. S. (2007). Outbreaks where food workers have been implicated in the spread of foodborne disease. Part 1. Description of the problem, methods, and agents involved. Journal of Food Protection, 70(7), 1752-1761.

Holmes, S. (2013). Fresh fruit, broken bodies: Migrant farmworkers in the United States. Berkeley: University of California Press.

Johns, G. (2010). Presenteeism in the workplace: A review and research agenda. Journal of Organizational Behavior, 31(4), 519-542. http://dx.doi.org/10.1002/job.630

Johns, G. (2011). Attendance dynamics at work: The antecedents and correlates of presenteeism, absenteeism, and productivity loss. Journal of Occupational Health Psychology, 16(4), 483-500. http://dx.doi.org/10.1037/a0025153 
Link, B. G., \& Phelan, J. (1995). Social conditions as fundamental causes of disease. Journal of Health and Social Behavior, 35, 80-94. http://dx.doi.org/10.2307/2626958

Lo, J., \& Jacobson, A. (2011). Human rights from field to fork: Improving labor conditions for food-sector workers by organizing across boundaries. Race/ Ethnicity: Multidisciplinary Global Contexts, 5(1), 61-82. http://dx.doi.org/10.2979/racethmulglocon.5.1.61

Lynch, M. F., Tauxe, R. V., \& Hedberg, C. W. (2009). The growing burden of foodborne outbreaks due to contaminated fresh produce: Risks and opportunities [Review]. Epidemiology and Infection, 137(3), 307-315. http://dx.doi.org/10.1017/S0950268808001969

Mitchell, R. E., Fraser, A. M., \& Bearon, L. B. (2007). Preventing food-borne illness in food service establishments: Broadening the framework for intervention and research on safe food handling behaviors. International Journal of Environmental Health Research, 17(1), 9-24. http://dx.doi.org/10.1080/09603120601124371

Mobed, K., Gold, E. B., \& Schenker, M. B. (1992). Occupational health problems among migrant and seasonal farm workers. West Journal of Medicine, 157(3), 367-373.

Muhr, T. (2014). ATLAS.ti Scientific Software Development GmbH (Version 7) [Computer software]. Berlin: Technical University.

Occupational Safety and Health Administration. (n.d.). Safety and health topics: Agricultural operations. Retrieved from https://www.osha.gov/dsg/ topics/agriculturaloperations/

Office of the Federal Register. (2011). A guide to the rulemaking process. Retrieved from https://www.federalregister.gov/uploads/2011/ 01/the_rulemaking_process.pdf

Oxfam America. (2013). Hard work, hard lives: Survey exposes harsh reality faced by low-wage workers in the U.S. Retrieved from http://www.oxfamamerica.org/ static/media/files/low-wage-worker-report-oxfamamerica.pdf

Phelan, J. C., Link, B. G., \& Tehranifar, P. (2010). Social conditions as fundamental causes of health inequalities: Theory, evidence, and policy implications. Journal of Health and Social Behavior, 51(1), S28-S40. http://dx.doi.org/10.1177/0022146510383498
Pope, C., Ziebland, S., \& Mays, N. (2000). Qualitative research in health care: Analysing qualitative data [Review]. British Medical Journal, 320(7227), 114-116. http://dx.doi.org/10.1136/bmj.320.7227.114

Quandt, S. A., Summers, P., Bischoff, W. E., Chen, H., Wiggins, M. F., Spears, C. R., \& Arcury, T. A. (2013). Cooking and eating facilities in migrant farmworker housing in North Carolina. American Journal of Public Health, 103(3), e78-e84. http://dx.doi.org/10.2105/AJPH.2012.300831

Ruggles, S., Alexander, J. T., Genadek, K., Goeken, R., Schroeder, M. B., \& Sobek, M. (2010). American Community Survey 3-year estimates (2008-2010), Integrated Public Use Microdata Series (Version 5.0) [Machine-readable database]. Minneapolis: Minnesota Population Center [producer and distributor].

Sakala, C. (1987). Migrant and seasonal farmworkers in the United States: A review of health hazards, status, and policy. International Migration Review, 21(3), 659-687. http://dx.doi.org/10.2307/2546616

Southern Poverty Law Center. (2010). Injustice on our plates: Immigrant women in the U.S. food industry. Retrieved from https://www.splcenter.org/sites/ default/files/d6 legacy files/downloads/ publication/Injustice on Our Plates.pdf

Standards for the growing, harvesting, packing, and holding of produce for human consumption, 78 Federal Register 3504 (January 16, 2013) (to be codified at 21 C.F.R. pts. 16 and 112).

U.S. Department of Agriculture, Economic Research Service. (2008). Farm labor background. Retrieved from http://www.ers.usda.gov/topics/farmeconomy/farm-labor/background.aspx

U. S. Department of Labor. (n.d.). Employee rights under the National Labor Relations Act. Retrieved February 19, 2013, from http://www.dol.gov/olms/regs/ compliance/EmployeeRightsPoster11x17 Final.pdf

U.S. Department of Labor. (2009). Wages and hours worked: Minimum wage and overtime pay. Retrieved August 27, 2014, from http://www.dol.gov/ compliance/guide/minwage.htm

U.S. Food and Drug Administration. (2011). Background on the Food Safety Modernization Act (FSMA). Retrieved from http://www.fda.gov/Food/ GuidanceRegulation/FSMA/ucm239907.htm 
U.S. Food and Drug Administration. (2013a). FSMA proposed rule for produce safety: Standards for the growing, harvesting, packing, and holding of produce for buman consumption. Retrieved February 5, 2014, and archived at https://web.archive.org/web/ 20150218070104/http://www.fda.gov/Food/ GuidanceRegulation/FSMA/ucm334114.htm

U.S. Food and Drug Administration. (2013b). Statement from FDA Deputy Commissioner for Foods and Veterinary Medicine, Michael Taylor, on key provisions of the proposed FSMA rules affecting farmers. Retrieved December 19, 2013, from http://www.fda.gov/Food/Guidance Regulation/FSMA/ucm379397.htm

U.S. Food and Drug Administration. (2014). FSMA proposed rule for preventive controls for human food: Current good manufacturing practice and hazard analysis and riskbased preventive controls for human food. Archived at https://web.archive.org/web/20131004103957/htt p://www.fda.gov/food/guidanceregulation/fsma/ ucm334115.htm

U.S. Food and Drug Administration, Retail Food Program Steering Committee. (2000). Report of the FDA Retail Food Program Database of Foodborne Illness Risk. Factors. Retrieved from http://www.fda.gov/ downloads/Food/GuidanceRegulation/ UCM123546.pdf

Villarejo, D. (2003). The health of U.S. hired farm workers [Review]. Annual Review of Public Health, 24, 175-193. http://dx.doi.org/10.1146/annurev. publhealth.24.100901.140901

Waugh, I. M. (2010). Examining the sexual harassment experiences of Mexican immigrant farmworking women. Violence Against Women, 16(3), 237-261. http://dx.doi.org/10.1177/1077801209360857 